\title{
The Mass Spectrometry of Taxol
}

\author{
Thomas D. McClure and Karl H. Schram
}

Department of Pharmaceutical Sciences, College of Pharmacy, University of Arizona, Tucson, Arizona, USA

\author{
Mark L. J. Reimer \\ Biomedical Mass Spectrometry Unit, McGill University, Montreal, Quebec, Canada
}

The antitumor agent taxol has been examined by electron ionization, chemical ionization, and fast atom bombardment mass spectrometry. Three ion series are observed: (1) the M-series, characteristic of the intact molecule; (2) the T-series, with fragments derived from the taxane ring; and (3) the $\mathrm{S}$-series representing the $\mathrm{C}-13$ side chain. Neutral losses dominate each series of ions and serve to verify the presence and number of functionalities in each portion of the molecule. Fragmentation pathways and mechanisms of ion formation are proposed on the basis of product ion analysis and accurate mass measurements. (J Am SoC Mass Spectrom 1992, 3, 672-679)

$\mathrm{T}$ he diterpenoid taxol (NCS-125973, 1) [1] is a promising experimental antitumor agent first isolated from the bark of the western yew, Taxus brevifolia, in 1971 [2]. The encouraging results from clinical trials [3-8] have led to increased activity in testing 1 for treatment of solid and leukemic cancers.

The small quantity of $\mathbf{1}$ present in the bark of the western yew, and the exhaustive extraction procedures [9] required for isolation of $\mathbf{1}$ from this limited natura] source, have spurred research efforts to develop synthetic methods for the preparation of this important antitumor agent and related structural analogs. As part of an ongoing effort to characterize antitumor agents and their analogs by mass spectrometry $[10,11]$, we examined the mass spectra of 1 using electron ionization (EI), chemical ionization (CI), and fast atom bombardment (FAB). Fragmentation pathways and mechanisms of ion decomposition are proposed on the basis of product ion analyses and exact mass determinations. The following information provides a reference basis for the mass spectral analysis of analogs and metabolites of $\mathbf{1}$.

Address reprint requests to Karl $H$. Schram, Department of Pharmaceutical Sciences, College of Pharmacy, University of Arizona, Tucson, AZ 85721 .

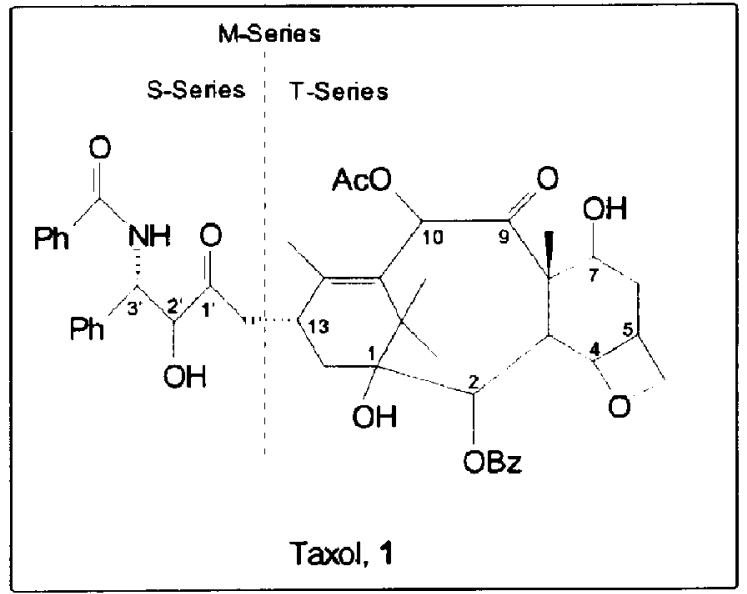

\section{Experimental}

\section{Materials}

An authentic sample of 1 was provided by the Drug Synthesis and Chemistry Branch of the Division of Cancer Treatment, National Cancer Institute (Washington, DC). Glycerol and sulfolane were obtained from 
Pierce Chemical Co. (Rockford, IL) and stored over molecular sieves.

\section{Electron Ionization Mass Spectrometry}

The EI mass spectra were acquired using a Finnigan MAT 90 double-focusing (BE) mass spectrometer (Finnigan MAT, San Jose, CA) equipped with a Micro VIP $11 / 73$ computer (US Design, Lanham, MD). Low-resolution EI mass spectra of 1 were obtained under the following conditions: ionizing energy, $70 \mathrm{eV}$; emission current, $1.0 \mathrm{~mA}$; source temperature, $200^{\circ} \mathrm{C}$; scan range, $m / z$ 70-1000; scan rate, $0.5 \mathrm{~s} /$ decade; resolution, 1000 (10\% valley definition). Sample introduction was via a heated $\left(250^{\circ} \mathrm{C}\right)$ direct insertion probe. For exact mass determinations, the resolution was adjusted to 7000; the scan rate, $10 \mathrm{~s} /$ decade; calibrant for accurate mass, perfluorokerosene (PFK) introduced through the reference inlet.

\section{Chemical Ionization Mass Spectrometry}

CI analyses were performed on the MAT 90 mass spectrometer under the following conditions: reagent gases, $\mathrm{NH}_{3}$ or $\mathrm{CH}_{4}$; ionizing energy, $225 \mathrm{eV}$; emission current, $0.2 \mathrm{~mA}$; source temperature, $120^{\circ} \mathrm{C}$; scan range, $m / z 70-1000$; scan rate, $0.5 \mathrm{~s} /$ decade; resolution, 1000 ; sample introduction, direct insertion probe heated to $250^{\circ} \mathrm{C}$.

\section{Fast Atom Bombardment Mass Spectrometry}

FAB mass spectra were acquired on a double-focusing (BE) mass spectrometer designed and built by AMD Intectra (Harpstedt, Germany). Data acquisition and instrument control were accomplished using two SAM 68K computers (KWS Computersysteme GmbH, Ettlingen, Germany) and software developed by AMD Intectra. Ionization involved the use of a $2.0-\mathrm{mA}$ primary beam of $\mathrm{Cs}^{+}$ions accelerated to $7.0 \mathrm{kV}$ above source potential. Other instrumental conditions included: source temperature, $35^{\circ} \mathrm{C}$; accelerating voltage, $6 \mathrm{kV}$; scan range, $m / z$ 100-1000; scan rate, $35 \mathrm{~s} /$ cycle; resolution, 1000. Taxol $(10-20 \mu \mathrm{g})$ was premixed with 10 $\mu \mathrm{L}$ of the matrix (glycerol or sulfolane) and allowed to stand overnight prior to analysis. Approximately $1 \mu \mathrm{L}$ of the sample-matrix mixture was applied to a stainless steel FAB target. All spectra were background subtracted following acquisition, to remove matrix ion contributions.

\section{Product Ion Analyses}

EI and CI product ions were produced by collision-induced decomposition (CID) of selected parent ions in the first field-free region of the MAT 90 and mass analyzed using a $B / E=$ constant linked scan. The kinetic energy release accompanying the CID process limited the product ion resolution to 500. The flow rate of the helium collision gas was adjusted so that the parent ion abundance was reduced by $50 \%$; masses were scanned from the parent ion to $m / z 50$ at a rate of $20 \mathrm{~s} /$ decade using a linear scan function. Ionization conditions were the same as described for low-resolution $\mathrm{EI}$ and $\mathrm{CI}\left(\mathrm{NH}_{3}\right)$.

FAB product ion studies were accomplished using the AMD mass spectrometer with ionization conditions as described for normal FAB analysis. The linked scan law was linear ( $B / E=$ constant) with a scan cycle time of $60 \mathrm{~s}$ for the mass range from parent mass to $m / z 50$. The CID conditions included the collision gas (argon) flow rate resulting in a $50 \%$ reduction of parent ion intensity.

\section{Results and Discussion}

Major fragment ions observed in the mass spectrum of 1 can be placed into three categories representative of the major portions of the molecule:

1. The molecular ion related series (M-series) includes the molecular ion $\left([\mathrm{M}]^{+-}\right)$, the protonated molecule $\left([\mathrm{MH}]^{+}\right)$, and other ion-molecular species (e.g., $\left[\mathrm{M}+\mathrm{NH}_{4}\right]^{+}$). Fragments formed by losses from either the taxane ring or the $C-13$ side chain, with the $\mathrm{O}-\mathrm{C}-13$ bond remaining intact, are also included in this ion series; neutral losses are the predominant mode of decomposition.

2. The taxane ring series (T-series) is comprised of ions formed by cleavage of the $\mathrm{O}-\mathrm{C}-13$ bond with the charge residing on the taxane ring system. Subsequent fragmentation involving the loss of functionalities attached to the taxine ring, as well as ions that may be formed by the cleavage of the taxane ring itself, are included in this category. Neutral losses are the predominant mode of decomposition and indicate the various substituents that are located on the taxane ring portion of the molecule.

3. The C-13 ester side-chain series (S-series) ions consist of the even-electron ion side chain $\left([S]^{+}\right)$and associated fragments and adducts. In general, the Sseries ions represent sequential cleavages that are useful in identifying the functional groups attached to this portion of the molecule. Various neutral losses are also observed and permit location of substituents in the side chain.

As might be expected, the number and intensity of fragment ions in the mass spectra of 1 varied according to the ionization method, with the FAB spectra showing considerably fewer fragment ions compared to the EI or CI spectra [12; This reference has reported the analysis of taxol by FAB (no matrix mentioned) and $\mathrm{CI}$ $\left(\mathrm{NH}_{3}\right.$ and butane). Discussion is limited to mentioning the loss of the $\mathrm{C}-13$ side chain and the comment that various esters are lost as neutral fragments]. However, the FAB spectrum using sulfolane as a matrix 


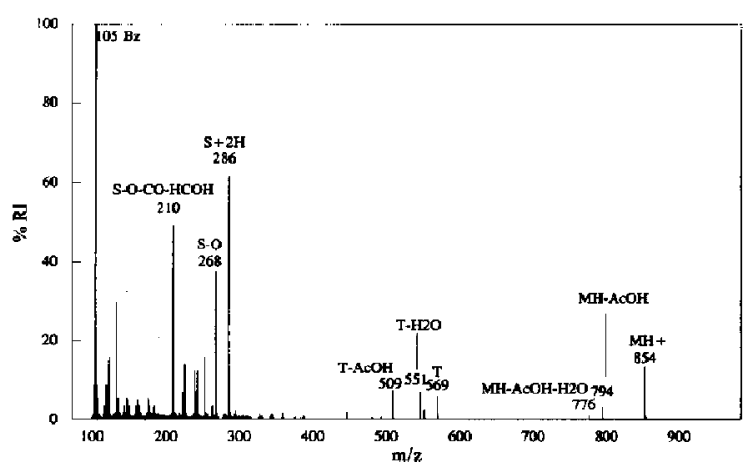

Figure 1. FAB (sulfolane) mass spectrum of taxol. Major matrix ion contributions have been subtracted; however, the unmarked ions are artifacts arising from incomplete matrix subtraction.

(Figure 1) displayed ions characteristic of each series: $[\mathrm{MH}]^{+},[\mathrm{T}]^{+}$, and $[\mathrm{S}-\mathrm{O}]^{+}$. ( $\mathrm{S}-\mathrm{O}$ is used to designate the ion formed by cleavage of the $\mathrm{O}-13, \mathrm{C}-1^{\prime}$ bond and does not imply loss of oxygen from the side chain.) The FAB (sulfolane) mass spectrum provided the best indication of the molecular weight of the intact molecule, with $\mathrm{MH}^{+}$at $m / z 854$ being more intense than that observed when glycerol was used as the matrix or in the CI spectra. (In contrast, the EI spectrum provided very little information on the intact molecule.) Furthermore, the presence of $[\mathrm{T}]^{+}$and $[\mathrm{S}-\mathrm{O}]^{+}$in both the $\mathrm{FAB}$ spectra indicate that cleavage of the $\mathrm{O}-\mathrm{C}-13$ bond is facile and important in formation of the $\mathrm{T}$ - and S-series of ions, in accord with product ion studies. The EI and CI spectra contained fragments from $[\mathrm{T}]^{+}$and $[\mathrm{S}-\mathrm{O}]^{+}$, allowing verification of the location of functional groups as being on the taxane ring or in the $\mathrm{C}-13$ side chain. The $\mathrm{CI}\left(\mathrm{CH}_{4}\right)$

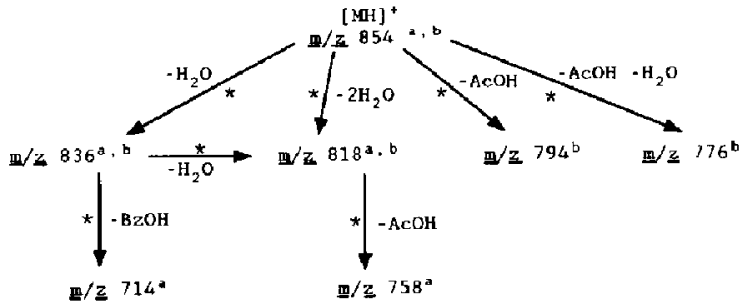

Figure 2. Fragmentation pathways as indicated by CID product ion studies for the $\mathrm{M}$-series ions under ${ }^{\mathrm{a}} \mathrm{CI}\left(\mathrm{NH}_{3}\right)$ and ${ }^{\mathrm{b}} \mathrm{FAB}$ (sulfolane) conditions. (*Indicates transition observed in product ion analysis.)

spectrum, while providing confirmation of some ion assigrments, did not reveal any additional structural information.

\section{M-Series}

Table 1 lists the structural assignments and relative abundances for the $\mathrm{M}$-series ions present in the EI, CI, and FAB mass spectra. The greatest number and most intense ions of the $\mathrm{M}$-series were observed in the $\mathrm{CI}$ $\left(\mathrm{NH}_{3}\right)$ spectrum. Figure 2 contains a fragmentation scheme based on $\mathrm{CI}\left(\mathrm{NH}_{3}\right)$ and FAB (sulfolane) product ion studies. Determination of elemental composition of the M-series ions was not possible due to the low intensity of ions (EI and $\mathrm{CI}\left(\mathrm{CH}_{4}\right)$ ) or lack of noninterfering mass reference compounds ( $\mathrm{FAB}$ and $\mathrm{CI}$ $\left(\mathrm{NH}_{3}\right)$ ). Nevertheless, a weak $[\mathrm{M}]^{+\cdot}$ ion at $\mathrm{m} / z 853$ was observed in the low-resolution EI mass spectrum of 1 that is consistent with the formula $\mathrm{C}_{47} \mathrm{H}_{51} \mathrm{NO}_{14}$ [2].

Table 1. Relative abundances and mass-to-charge ratio values of the M-series ions present in the EI, CI, and $\mathrm{FAB}$ mass spectra

\begin{tabular}{|c|c|c|c|c|c|c|}
\hline$m / 2$ & EI & $\mathrm{Cl}\left(\mathrm{CH}_{4}\right)$ & $\mathrm{Cl}\left(\mathrm{NH}_{3}\right)$ & $\mathrm{FAB}^{\mathrm{a}}$ & $\mathrm{FAB}^{\mathrm{b}}$ & Assignment \\
\hline 871 & - & - & 2.4 & - & - & {$\left[\mathrm{MH}+\mathrm{NH}_{3}\right]^{+}$} \\
\hline 854 & - & - & 1.9 & 5.7 & 13.4 & {$[\mathrm{MH}]^{+}$} \\
\hline 853 & 0.01 & - & - & - & - & {$[\mathbf{M}]^{+}$} \\
\hline 836 & - & 0.1 & 11.9 & - & - & {$\left[\mathrm{MH}-\mathrm{H}_{2} \mathrm{O}\right]^{+}$} \\
\hline 835 & 0.02 & - & - & - & - & {$\left[\mathrm{M}-\mathrm{H}_{2} \mathrm{O}\right]^{+}$} \\
\hline 818 & - & - & 10.1 & - & - & {$\left[\mathrm{MH}-2 \mathrm{H}_{2} \mathrm{O}\right]^{+}$} \\
\hline 794 & - & - & - & - & 1.9 & {$[\mathrm{MH}-\mathrm{AcOH}]^{+}$} \\
\hline 793 & 0.03 & - & - & - & - & {$[\mathrm{M}-\mathrm{AcOH}]^{+}$} \\
\hline 776 & - & - & 3 & - & 1 & {$\left[\mathrm{MH}-\mathrm{AcOH}-\mathrm{H}_{2} \mathrm{O}\right]^{+}$} \\
\hline 776 & 0.4 & - & - & - & - & {$[\mathrm{M}-\mathrm{ACOH}-\mathrm{OH}]^{\prime}$} \\
\hline 758 & - & - & - & - & - & {$\left[\mathrm{MH}-\mathrm{AcOH}-\mathrm{H}_{2} \mathrm{O}\right]^{+}$} \\
\hline 754 & 0.2 & - & - & - & - & Mot Assigned \\
\hline 733 & - & - & 2.8 & - & - & {$\left[\mathrm{MH}-\mathrm{BzNH}_{2}\right]^{+}$} \\
\hline 715 & 0.2 & - & - & - & - & {$\left[\mathrm{M}-2 \mathrm{AcOH}-\mathrm{H}_{2} \mathrm{O}\right]^{+}$.} \\
\hline 714 & - & - & 13.3 & - & - & {$\left[\mathrm{MH}-\mathrm{BzOH}-\mathrm{H}_{2} \mathrm{O}\right]^{+}$} \\
\hline 654 & - & - & - & - & - & {$\left[\mathrm{MH}-\mathrm{BzOH}-\mathrm{AcOH}-\mathrm{H}_{2} \mathrm{O}\right]^{+}$} \\
\hline 654 & 0.09 & - & - & - & - & {$[\mathrm{M}-\mathrm{BzOH}-\mathrm{AcOH}-\mathrm{OH}]^{+}$} \\
\hline
\end{tabular}

Matrix was glycerol.

DMatrix was sulfolane. 
Many M-series fragments result from neutral losses involving various substituents. The loss of $\mathrm{H}_{2} \mathrm{O}$ was observed in EI $\left(\left[\mathrm{M}-\mathrm{H}_{2} \mathrm{O}\right]^{+\cdot} ; m / z\right.$ 835) and $\mathrm{CI}$ $\left(\left[\mathrm{MH}-\mathrm{H}_{2} \mathrm{O}\right]^{+}, m / z\right.$ 836), while the loss of two molecules of $\mathrm{H}_{2} \mathrm{O}$ ([MH-2 $\left.\mathrm{H}_{2} \mathrm{O}\right]^{+}, m / z$ 818) was evident in the $\mathrm{CI}\left(\mathrm{NH}_{3}\right)$ mass spectrum.

While the absolute position of the hydroxyls involved in the loss of water cannot be determined from the mass spectra of 1 , the loss of the $2^{\prime}-\mathrm{OH}$ with a $\gamma$ - or 8-hydrogen (as is generally observed in the EI spectra of simple alkanols) would not result in a stable structure, a fact that is consistent with the absence of an $\left[\mathrm{S}-\mathrm{O}-\mathrm{H}_{2} \mathrm{O}\right]^{+}$ion in any of the spectra. Consequently, in $\mathrm{M}$-series ions, losses of water are believed to involve the taxane-ring hydroxyl groups.

Fragments corresponding to the loss of acetic acid ( $\mathrm{ACOH}$ ) were seen in the EI and FAB (sulfolane) mass spectra ( $m / z 793$ and 794 , respectively), verifying the

Table 2. Relative abundances and mass-to-charge ratio values of the T-series and S-series ions present in the EI, CI, and FAB mass spectra

\begin{tabular}{|c|c|c|c|c|c|c|}
\hline$m / z$ & $\mathrm{El}$ & $\mathrm{Cl}\left(\mathrm{CH}_{4}\right)$ & $\mathrm{Cl}\left(\mathrm{NH}_{3}\right)$ & $\mathrm{FAB}^{\mathrm{a}}$ & $F A B^{B}$ & Assignment \\
\hline 586 & - & - & 20.9 & - & - & {$\left[\mathrm{T}+\mathrm{NH}_{3}\right]^{+}$} \\
\hline 569 & - & 6.8 & 10.8 & 2.4 & 5.8 & {$[\mathrm{~T}]^{+}$} \\
\hline 568 & 0.2 & - & - & - & - & {$[\mathbf{T}-\mathbf{H}]^{+.}$} \\
\hline 553 & - & - & 23.9 & - & - & Not assigned \\
\hline 551 & - & 4.8 & 19.5 & - & 2.4 & {$\left[\mathrm{~T}-\mathrm{H}_{2} \mathrm{O}^{+}\right.$} \\
\hline 550 & 0.1 & - & - & - & - & {$\left[\mathbf{T}-\mathbf{H}-\mathbf{H}_{\mathbf{2}} \mathrm{O}\right]^{+}$} \\
\hline 533 & - & - & - & - & - & {$\left[\mathrm{T}-2 \mathrm{H}_{2} \mathrm{O}\right]^{+}$} \\
\hline 527 & 0.6 & - & - & - & - & {$[\mathrm{T}-\mathrm{H}-\mathrm{COCH}]^{+}$} \\
\hline 526 & 0.3 & - & - & - & - & {$\left[\mathrm{T}-\mathrm{H}-\mathrm{COCH}_{2}\right]^{+}$} \\
\hline 526 & - & - & 17.2 & - & - & {$\left[\mathrm{T}+\mathrm{NH}_{3}-\mathrm{AcOH}\right]^{+}$} \\
\hline 509 & - & 35.8 & 16 & 39.8 & 7.4 & {$[\mathrm{~T}-\mathrm{AcOH}]^{+}$} \\
\hline 508 & 2 & - & - & - & - & {$[\mathrm{T}-\mathrm{H}-\mathrm{AcOH}]^{+}$.} \\
\hline 491 & - & 7.1 & 9.8 & - & - & {$\left[\mathrm{T}-\mathrm{AcOH}-\mathrm{H}_{2} \mathrm{O}\right]^{+}$} \\
\hline 490 & 0.6 & - & - & - & - & {$\left[\mathbf{T}-\mathrm{H}-\mathrm{AcOH}-\mathrm{H}_{2} \mathrm{O}^{+-}\right.$} \\
\hline 480 & 0.9 & - & - & - & - & {$[\mathbf{T}-\mathrm{H}-\mathrm{AcOH}-\mathrm{CO}]^{+}$} \\
\hline 466 & 0.1 & - & - & - & - & {$\left[\mathrm{T}-\mathrm{H}-\mathrm{AcOH}-\mathrm{COCH}_{2}\right]^{+}$.} \\
\hline 464 & - & - & 10.9 & - & - & {$\left[\mathrm{T}+\mathrm{NH}_{3}-\mathrm{BzOH}\right]^{+}$} \\
\hline 448 & 0.4 & - & - & - & - & {$[\mathrm{T}-\mathrm{H}-2 \mathrm{AcOH}]^{+}$} \\
\hline 447 & - & 34.2 & 13.3 & - & 2.1 & {$[\mathrm{~T}-\mathrm{BzOH}]^{+}$} \\
\hline 447 & 0.4 & - & - & - & - & {$[\mathbf{T}-\mathbf{H}-\mathbf{B z O}]^{+}$} \\
\hline 446 & 0.7 & - & - & - & - & {$[\mathrm{T}-\mathrm{H}-\mathrm{BzOH}]^{+}$} \\
\hline 430 & 0.3 & - & - & - & - & {$\left[\mathrm{T}-\mathrm{H}-2 \mathrm{AcOH}-\mathrm{H}_{2} \mathrm{O}\right]^{+}$} \\
\hline 404 & 0.8 & - & - & - & - & {$\left[\mathrm{T}-\mathrm{H}-\mathrm{BzOH}-\mathrm{COCH}_{2}\right]^{+}$. } \\
\hline 404 & - & - & 5.3 & - & - & {$\left[\mathrm{T}+\mathrm{NH}_{3}-\mathrm{BzOH}-\mathrm{AcOH}\right]^{+}$} \\
\hline 387 & - & $\mathbf{3 3 . 1}$ & 22.2 & - & - & {$[\mathrm{T}-\mathrm{BzOH}-\mathrm{AcOH}]^{+}$} \\
\hline 386 & 1.7 & - & - & - & - & {$[\mathrm{T}-\mathrm{H}-\mathrm{BzOH}-\mathrm{AcOH}]^{+}$} \\
\hline 369 & - & 18.1 & 5.9 & - & - & {$\left[\mathrm{T}-\mathrm{BzOH}-\mathrm{AcOH}-\mathrm{H}_{2} \mathrm{O}\right]^{+}$} \\
\hline 368 & 0.6 & & & - & - & {$\left[\mathrm{T}-\mathrm{H}-\mathrm{Bz} \mathrm{OH}-\mathrm{AcOH}-\mathrm{H}_{2} \mathrm{O}\right]^{+}$} \\
\hline 344 & 0.7 & - & - & - & - & {$\left[\mathrm{T}-\mathrm{H}-\mathrm{BzOH}-\mathrm{ACOH}-\mathrm{COCH}_{2}\right]$} \\
\hline 344 & - & - & 2.4 & - & - & {$\left[\mathrm{T}+\mathrm{NH}_{3}-\mathrm{BzOH}-2 \mathrm{AcOH}\right]^{+}$} \\
\hline 343 & 0.8 & - & - & - & - & {$\left[\mathrm{T}-\mathrm{H}-\mathrm{Bz} \mathrm{OH}-\mathrm{ACOH}-\mathrm{CH}_{3} \mathrm{CO}\right]$} \\
\hline 327 & - & 41.2 & 7.1 & - & - & {$[\mathrm{T}-\mathrm{BzOH}-2 \mathrm{AcOH}]^{+}$} \\
\hline 326 & 1.9 & - & - & - & - & {$[\mathrm{T}-\mathrm{H}-\mathrm{BzOH}-2 \mathrm{AcOH}]^{+}$} \\
\hline 309 & - & 24.3 & 5.3 & - & - & {$\left[\mathrm{T}-\mathrm{BzOH}-2 \mathrm{AcOH}-\mathrm{H}_{2} \mathrm{O}^{+}\right.$} \\
\hline 308 & 1.2 & - & - & - & - & {$\left[\mathrm{T}-\mathrm{H}-\mathrm{Bz} \mathrm{OH}-2 \mathrm{AcOH}-\mathrm{H}_{2} \mathrm{O}^{+}\right.$} \\
\hline 303 & - & - & 35.6 & - & - & {$\left[\mathrm{S}+2 \mathrm{H}+\mathrm{NH}_{3}\right]^{+}$} \\
\hline 286 & 4.5 & 59.2 & 41.9 & 31.2 & 61.8 & {$[\mathrm{~S}+2 \mathrm{H}]^{+}$} \\
\hline 268 & 10.8 & 28.3 & 100 & 8.8 & 37.6 & {$[\mathrm{~S}-\mathrm{o}]^{+}$} \\
\hline 240 & 5 & 17.4 & 5.7 & - & - & {$[\mathbf{s}-\mathrm{O}-\mathrm{Co}]^{+}$} \\
\hline 222 & 14.6 & 10.8 & 4.6 & - & - & {$\left[\mathrm{S}-\mathrm{O}-\mathrm{CO}-\mathrm{H}_{2} \mathrm{O}\right]^{+}$} \\
\hline 210 & 25.7 & 36.1 & 6.3 & - & 49.4 & {$[\mathrm{~S}-\mathrm{O}-\mathrm{CO}-\mathrm{HCOH}]^{+}$} \\
\hline 193 & 11.6 & - & 4.4 & - & - & {$\left[\mathrm{S}-\mathrm{O}-\mathrm{CO}-\mathrm{HCOH}-\mathrm{NH}_{3}\right]^{+}$} \\
\hline
\end{tabular}


presence of at least one acetyl group in 1 . Since 1 contains acetyl groups at C-4 and C-10, identification of the specific acetyl group eliminated is not possible.

A relatively strong ion corresponding to loss of benzoic acid $(\mathrm{BzOH})$ and $\mathrm{H}_{2} \mathrm{O}$ from $[\mathrm{MH}]^{+}$is observed in the $\mathrm{CI}\left(\mathrm{NH}_{3}\right)$ spectrum $\left(\left[\mathrm{MH}-\mathrm{H}_{2} \mathrm{O}-\mathrm{BzOH}\right]^{+}\right.$, $m / z$ 714). A possible mechanism for formation of this ion begins with the loss of water to form $m / z 836$ followed by elimination of $\mathrm{BzOH}$ to give the $m / z 714$ ion, a sequence confirmed by product ion studies (Figure 2). The rationale for the proposed mechanism is based on the absence of an $[\mathrm{MH}-\mathrm{BzOH}]^{+}$ion in the $\mathrm{CI}$ and $\mathrm{FAB}$ spectra, suggesting that formation of $\mathrm{m} / z$ 732 is not a favored process. Loss of $\mathrm{H}_{2} \mathrm{O}$ to produce $m / z 836$ is thought to activate the elimination of $\mathrm{BzOH}$, a process driven by allylic resonance stabilization of the product ion $(m / z 714)$. As to the site of the activating $\mathrm{H}_{2} \mathrm{O}$ elimination, loss of the $\mathrm{C}-7$ hydroxyl group does not result in a structure that would facilitate removal of the C-2 benzoyl group. Conversely, loss of the C-1 hydroxyl group and one of the C-14 protons results in unsaturation between $\mathrm{C}-1$ and $\mathrm{C}-14$. This unsaturation reduces the energy required for loss of the benzoyl group (as benzoic acid) by the formation of a stable product ion.

Other neutral losses observed for the $\mathrm{M}$-series can be complex and include $\left[\mathrm{MH}-\mathrm{H}_{2} \mathrm{O}-\mathrm{AcOH}\right]^{+}, m / z$ 776; $\left[\mathrm{MH}-2 \mathrm{H}_{2} \mathrm{O}-\mathrm{AcOH}\right]^{+}, m / z$ 758; and $\left[\mathrm{MH}-\mathrm{H}_{2} \mathrm{O}-\right.$ $\mathrm{AcOH}-\mathrm{BzOH}]^{+}, m / z$ 654. Again, the presence of more than one like functionality precludes assignment of the specific sites from which these losses occur.

\section{T-Series}

Table 2 lists the mass-to-charge ratio and relative intensities of the T-series ions observed in the $\mathrm{EI}, \mathrm{CI}$, and FAB mass spectra. Structural assignments and proposed mechanisms of ion formation are based on low- and high-resolution mass measurements (EI, Tables 2 and 3) and product ion CID studies in EI (Figure 3) and $\mathrm{CI}\left(\mathrm{NH}_{3}\right)$ (Figure 4). Compared to the M-series, the T-series ions are generally present in greater numbers and at higher relative abundances for both modes of ionization. Cleavage of the $\mathrm{C}-13$ side chain results in a stable ion series consisting of the taxane ring system ion $\left([\mathrm{T}-\mathrm{H}]^{+}\right.$or $\left.[\mathrm{T}]^{+}\right)$and ions arising by subsequent neutral loss of $\mathrm{H}_{2} \mathrm{O}, \mathrm{ACOH}$ and $\mathrm{BzOH}$. Facile cleavage of the $\mathrm{C}-13$ side chain has also been observed under conditions of mild base-catalyzed methanolysis and oxidative conditions with basic manganese dioxide in acetone [2].

The EI spectrum of 1 contained a weak $[\mathrm{T}-\mathrm{H}]^{+}$. ( $m / z 568)$, which can be formed from [M] ${ }^{+}$via a McLafferty rearrangement. The side chain is lost as a neutral molecule, while the positive charge or radical site at $\mathrm{C}-13$ is stabilized by conjugation with the $\mathrm{C}-12$ double bond. The $[T]^{+}$ion $(m / z 569)$ observed in the $\mathrm{CI}$ and $\mathrm{FAB}$ mass spectra may arise from $[\mathrm{MH}]^{+}$by

Table 3. Accurate mass and ion composition data of T- and S-series ions under high-resolution EI conditions

\begin{tabular}{cccc}
\hline Calculated mass & Observed mass & Formula & Error (mDa) \\
\hline 568.2310 & 568.2281 & $\mathrm{C}_{31} \mathrm{H}_{36} \mathrm{O}_{10}$ & 2.9 \\
551.2282 & 551.2299 & $\mathrm{C}_{31} \mathrm{H}_{35} \mathrm{O}_{9}$ & 1.7 \\
526.2204 & 526.2243 & $\mathrm{C}_{29} \mathrm{H}_{34} \mathrm{O}_{9}$ & 3.9 \\
508.2098 & 508.2110 & $\mathrm{C}_{29} \mathrm{H}_{32} \mathrm{O}_{8}$ & 1.2 \\
490.1993 & 490.2005 & $\mathrm{C}_{29} \mathrm{H}_{30} \mathrm{O}_{7}$ & 1.2 \\
480.2149 & 480.2163 & $\mathrm{C}_{28} \mathrm{H}_{32} \mathrm{O}_{7}$ & 1.4 \\
466.1993 & 466.2028 & $\mathrm{C}_{27} \mathrm{H}_{30} \mathrm{O}_{7}$ & 3.5 \\
448.1887 & 448.1993 & $\mathrm{C}_{27} \mathrm{H}_{28} \mathrm{O}_{6}$ & 0.6 \\
446.1942 & $\mathrm{C}_{24} \mathrm{H}_{30} \mathrm{O}_{8}$ & -2.1 \\
430.1781 & 446.1921 & $\mathrm{C}_{27} \mathrm{H}_{25} \mathrm{O}_{5}$ & 3.7 \\
404.1836 & $\mathrm{C}_{22} \mathrm{H}_{28} \mathrm{O}_{7}$ & 0.6 \\
386.1730 & $\mathrm{C}_{22} \mathrm{H}_{25} \mathrm{O}_{6}$ & -2.8 \\
368.1625 & $\mathrm{C}_{22} \mathrm{H}_{24} \mathrm{O}_{5}$ & 4.2 \\
344.1625 & 304.1842 & $\mathrm{C}_{20} \mathrm{H}_{24} \mathrm{O}_{5}$ & 1.7 \\
343.1546 & 386.1702 & $\mathrm{C}_{20} \mathrm{H}_{23} \mathrm{O}_{5}$ & -3.8 \\
326.1519 & 368.1667 & $\mathrm{C}_{20} \mathrm{H}_{22} \mathrm{O}_{4}$ & 0.0 \\
308.1413 & 344.1642 & $\mathrm{C}_{20} \mathrm{H}_{20} \mathrm{O}_{3}$ & 0.7 \\
268.0975 & 343.1508 & $\mathrm{C}_{16} \mathrm{H}_{14} \mathrm{NO}_{3}$ & -0.5 \\
240.1025 & 326.1519 & $\mathrm{C}_{15} \mathrm{H}_{14} \mathrm{NO}_{2}$ & 0.1 \\
222.0920 & 308.1420 & $\mathrm{C}_{15} \mathrm{H}_{12} \mathrm{NO}$ & -0.3 \\
210.0920 & 268.0970 & $\mathrm{C}_{14} \mathrm{H}_{12} \mathrm{NO}$ & -3.8 \\
122.0368 & 240.1026 & $\mathrm{C}_{7} \mathrm{H}_{6} \mathrm{O}_{2}$ & 1.2 \\
105.0341 & 222.0917 & $\mathrm{C}_{7} \mathrm{H}_{5} \mathrm{O}$ & -3.1 \\
91.0548 & 210.0882 & $\mathrm{C}_{7} \mathrm{H}_{7}$ & 0.6 \\
\hline
\end{tabular}




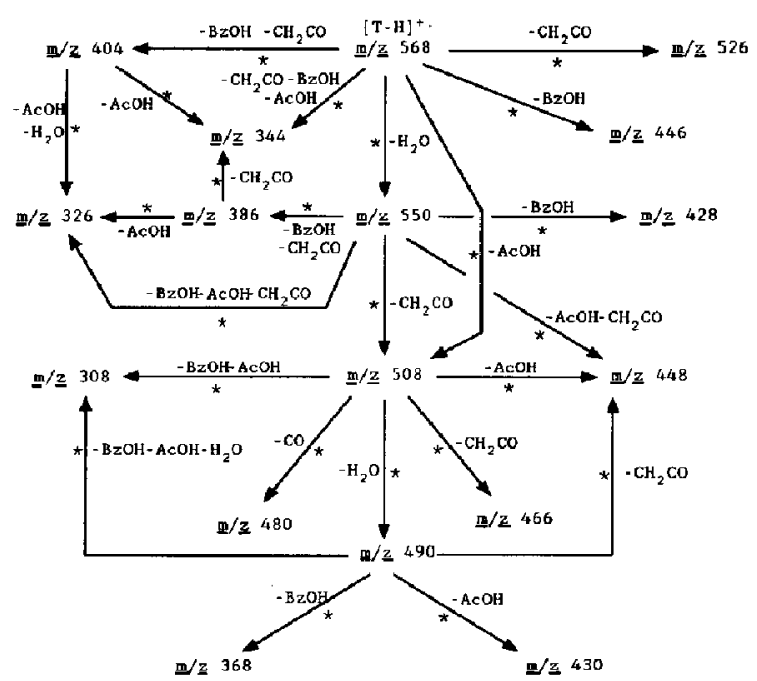

Figure 3. T-series ion fragmentation pathways as observed under EI/CID conditions. (*Indicates transition observed in product ion analysis.)

protonation of the $\mathrm{C}-\mathrm{1}^{\prime}$ carbonyl followed by cleavage of the $\mathrm{O}-\mathrm{C}-13$ bond generating a resonance-stabilized cation.

T-series ions observed in the $\mathrm{CI}\left(\mathrm{NH}_{3}\right)$ mass spectra show fragments arising from the elimination of two water molecules, verifying the presence of two hydroxyl groups on the taxane ring portion of 1 .

The T-series ions also appear as fragments representing the loss of one or two molecules of $\mathrm{AcOH}$ and are present in the EI, CI, and FAB spectra. In addition, the EI spectrum contains ions consistent with the elimination of ketene $\left(\mathrm{CH}_{2} \mathrm{CO}\right)$ from the acetyl groups [13], results that are supported by exact mass (Table 3 ) and product ion data (Figure 3 and Figure 4). The losses of neutral molecules of acetic acid and ketene further verify the presence of two acetyl groups on the taxane ring.

The peaks at $m / z 446\left(\mathrm{EI},[\mathrm{T}-\mathrm{H}-\mathrm{BzOH}]^{+}\right), 447(\mathrm{CI}$, $\left.[\mathrm{T}-\mathrm{BzOH}]^{+}\right)$and $464\left(\mathrm{CI}\left(\mathrm{NH}_{3}\right),\left[\mathrm{T}+\mathrm{NH}_{3}-\mathrm{BzOH}\right]^{+}\right)$

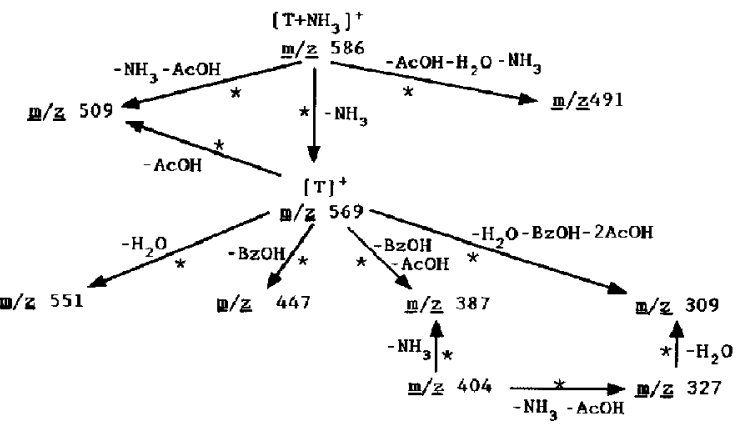

Figure 4. T-series fragmentation of pathway as observed under $\mathrm{CI}\left(\mathrm{NH}_{3}\right) / \mathrm{CID}$ conditions. ("Indicates transition observed in product ion analysis.) represent the loss of $\mathrm{BzOH}$ from $[\mathrm{T}]^{+}$and $[\mathrm{T}-\mathrm{H}]^{+}$; indicating the presence of the benzoyl group on the taxane ring portion of 1 . Elimination of $\mathrm{BzOH}$ in the $\mathrm{T}$-series is analogous to the loss of $\mathrm{BzOH}$ in the $\mathrm{M}$ series, and cleavage of the $\mathrm{C}-13$ side chain (to produce $[\mathrm{T}]^{+}$or $[\mathrm{T}-\mathrm{H}]^{+-}$) is believed to provide a pathway for loss of the $\mathrm{C}-2$ benzoyl group, similar to that described in the $\mathrm{M}$-series (i.e., $\left[\mathrm{MH}-\mathrm{H}_{2} \mathrm{O}-\mathrm{BzOH}\right]^{+}$).

Assignment of the $m / z 480$ peak in the EI spectrum as resulting from the sequence $[\mathrm{T}-\mathrm{H}-\mathrm{AcOH}-\mathrm{CO}]^{+\cdot}$ is supported by accurate mass analysis (Table 3) and by the observation of $m / z \quad 480$ as being a product of $[\mathrm{T}-\mathrm{H}-\mathrm{AcOH}]^{+}(\mathrm{m} / \mathrm{z} 508)$. The site of CO loss has not been determined but may involve elimination of the carbonyl group at C-9 leading to contraction or opening of the taxane ring. Further investigations of this ion are in progress.

Opening of the taxane ring skeleton of 1 by EI, as reported for taxinol 2 [14], was not observed. Fragmentation of 2 is thought to involve scission of the bonds joining the two six-membered rings of the skeleton (C-1/C-2, C-10/C-11 and C-2/C-3, C-9/C-10), resulting in formation of ions at $m / z 135,137$, and 107 . The EI spectrum of 1 did not contain ions, suggesting cleavage of the corresponding bonds in the taxane skeleton.

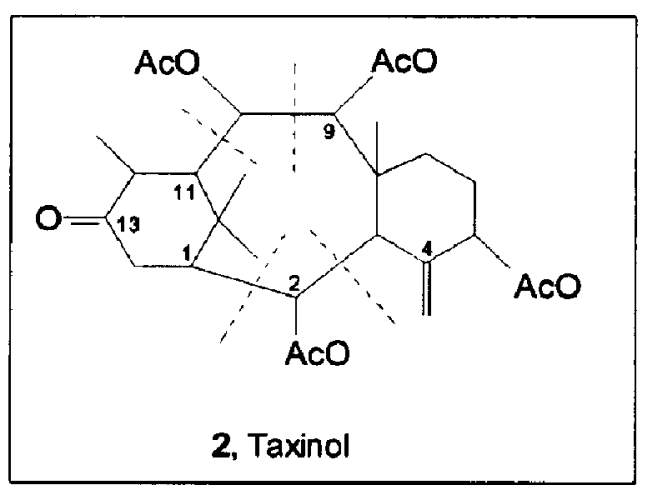

Cleavage of the oxetane ring in 1 may be expected to produce unsaturation between $C-4$ and $C-5$ and loss of a neutral molecule of formaldehyde, as observed in related systems [15]. However, such a loss of $\mathrm{HCOH}$ was not observed in the mass spectra of 1 .

Differentiation of functional groups located in the taxane ring from those in the side chain is possible using the T-series ions. Thus, a minimum of two hydroxyl groups, two acetate functionalities, and a benzoate residue can be identified as being located in the taxane portion of the molecule. Ions in this series are weak, but plentiful, in the EI spectrum. The most structurally informative data are obtained using CI with ammonia as the reagent gas, while the FAB spectrum in sulfolane also shows the major components present in 1. 


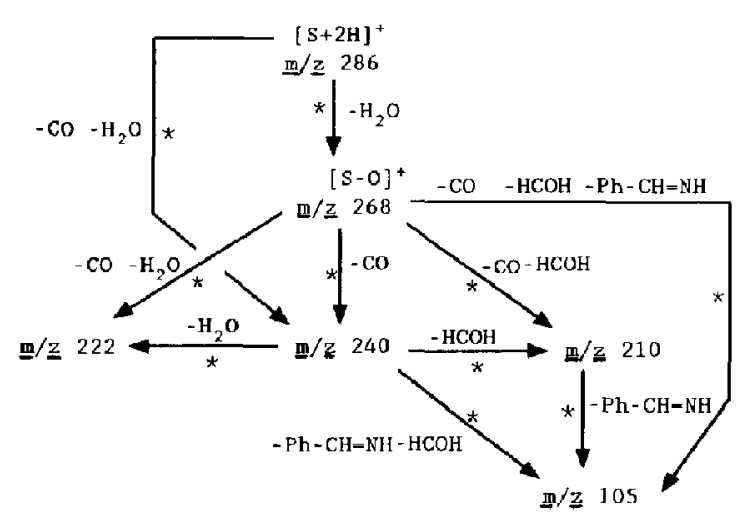

Figure 5. Fragmentation pathways suggested by EI/CID studies for the S-series ions. (*Indicates transition observed in product ion analysis.)

\section{S-Series}

Table 2 also lists the S-series ions observed in the mass spectra of 1 , with accurate mass values being given in Table 3 and fragmentation pathways indicated from product scans (EI) shown in Figure 5.

Formation of the $[\mathrm{S}+2 \mathrm{H}]^{+}$ion $(m / z$ 286) from $[\mathrm{M}]^{+\cdot}$ is thought to occur by rearrangement of two hydrogen atoms in a "Mclafferty +1 " mechanism, a fragmentation characteristic of esters [16]. An important aspect of this mechanism is the resonance stabilization of $[\mathrm{S}+2 \mathrm{H}]^{+}$.

Elimination of water from $[\mathrm{S}+2 \mathrm{H}]^{+}$to give $[\mathrm{S}-\mathrm{O}]^{+}$ is abserved in the EI product ion spectrum of $m / z 286$ (shown in the fragmentation scheme in Figure 5), but the low intensity of the $[\mathrm{S}-\mathrm{O}]^{+}$product ion suggests the existence of another route of formation of this ion. A plausible mechanism for the formation of $[\mathrm{S}-\mathrm{O}]^{+}$ ( $m / z 268$ ) from $[\mathrm{M}]^{+}$involves an $\alpha$-cleavage of the $\mathcal{O}$ $-\mathrm{C}-1^{\prime}$ bond with retention of the charge in the side chain fragment. The $[S-O]^{+}$ion was also prominent in the $\mathrm{CI}$ and FAB spectra.

An ion representing the loss of $\mathrm{H}_{2} \mathrm{O}$ from $[\mathrm{S}-\mathrm{O}]^{+}$is absent from the spectrum of 1 , while the consecutive loss of $\mathrm{CO}$ and $\mathrm{H}_{2} \mathrm{O}$ was observed. Two ions, $[\mathrm{S}-\mathrm{O}-\mathrm{CO}]^{+}(\mathrm{m} / \mathrm{z} 240)$ and $\left[\mathrm{S}-\mathrm{O}-\mathrm{CO}-\mathrm{H}_{2} \mathrm{O}\right]^{+}(\mathrm{m} / \mathrm{z}$ 222) are observed in the product ion spectrum of $[\mathrm{S}-\mathrm{O}]^{+}$. Product ion studies show that the ion $\left[\mathrm{S}-\mathrm{O}-\mathrm{CO}-\mathrm{H}_{2} \mathrm{O}\right]^{+}$results from $[\mathrm{S}-\mathrm{O}-\mathrm{CO}]^{+}$, indicating that the loss of $\mathrm{CO}$ and $\mathrm{H}_{2} \mathrm{O}$ occur by both concerted and sequential processes. A possible mechanism for this reaction involves localization of charge on $\mathrm{O}-1^{\prime}$ leading to loss of $\mathrm{CO}$, with the resulting cation being localized on $C-2^{\prime}$. Abstraction of the $C-3^{\prime}$ proton by the hydroxyl functionality at C-2' effects the elimination of $\mathrm{H}_{2} \mathrm{O}$ and results in formation of a resonance-stabilized ion at $m / z 222$.

An ion corresponding to [S-O-CO-HCHO] ${ }^{+}(\mathrm{m} / \mathrm{z}$ $210)$ is observed in the $\mathrm{EI}, \mathrm{CI}\left(\mathrm{CH}_{4}\right), \mathrm{CI}\left(\mathrm{NH}_{3}\right)$ and FAB (sulfolane) mass spectra. Formation of this ion is rationalized by a simple inductive cleavage of the C-2', C-3' bond, which is supported by product ion studies (Figure 5).

Finally, formation of a benzoyl ion at $m / z 105$ from both $m / z 210$ and $m / z 240$ is observed (Figure 5 ). The processes involve the loss of a neutral molecule of $\mathrm{Ph}$ $-\mathrm{CH}=\mathrm{NH}$ from $m / z 210$ and neutral molecules of $\mathrm{HCHO}$ and $\mathrm{Ph}-\mathrm{CH}=\mathrm{NH}$ from $m / z 240$. The $m / z$ 105 ion also can arise from the benzoyl group at C-2 in the taxane ring, and modifications to the terminal benzoyl group of the $\mathrm{C}-13$ side chain can be monitored in the product ion spectra of the S-series of ions. Site-specific changes to other positions in the $C-13$ side chain also can be detected by monitoring the S-series of ions.

Unlike the M- and T-series of ions, which do not provide the exact location of hydroxyl or acetyl groups on the taxane ring, the S-ion series shows the location of the following: (1) carbonyl group at C-1', (2) hydroxyl group at C-2', and (3) phenyl and benzamide groups at $\mathrm{C}-3^{\prime}$. 'Thus, changes in functionality at $\mathrm{C}-\mathbf{1}^{\prime}$, $C-2^{\prime}$, and $C-3^{\prime}$ can be monitored by mass spectrometry. The largest number of side-chain related ions were observed in the $\mathrm{EI}$ and $\mathrm{CI}\left(\mathrm{NH}_{3}\right)$ spectra, yet the FAB (sulfolane) spectrum did contain ions indicating the major functionalities of the side chain.

\section{Conclusion}

The mass spectral analysis of taxol provides information on the molecular weight, types of functional groups present, and the location of some of the functionalities. Molecular weight confirmation is obtained by the appearance of $[\mathrm{MH}]^{+}$in $\mathrm{CI}\left(\mathrm{NH}_{3}\right)$ and $\mathrm{FAB}$, $\left[\mathrm{M}+\mathrm{NH}_{4}\right]^{+}$in $\mathrm{CI}\left(\mathrm{NH}_{3}\right)$, and $[\mathrm{M}]^{+}$in the EI mass spectrum. The $\mathrm{M}$ - and $\mathrm{T}$-series of ions (especially with CI $\left(\mathrm{NH}_{3}\right)$ ) verify the presence of one benzoyl, two acetyl, and two hydroxyl groups attached to the taxine ring, as well as ions that may be formed by the cleavage of the taxane ring. While site-specific identification of hydroxyl and acetyl groups lost during fragmentation will require the analysis of isotopically labeled analogs of 1 , ions from both series can be used to monitor functional group changes in the taxane ring arising from metabolic processes or synthetic modifications. Site-specific changes in the important $\mathrm{C}-13$ side chain can be detected by monitoring ions in the S-series (fragmentation of the side chain in EI and CI) and the M-series ions.

In the future, mass spectrometry will play an important role in the monitoring of synthetically and metabolically induced alterations to the basic taxol structure, and this work provides the basis from which such studies may start.

\section{Acknowledgments}

We acknowledge the assistance of P. F. Baker and W. M. Hammargren in the operation and maintenance of the mass spectrometers and Karen F. McClure for careful criticism of the manuscript. 
Samples of taxol were supplied by the Drug Synthesis and Chemistry Branch, Division of Cancer Treatment, National Carcer Institute. This work was supported by National Institutes of Health grant CA 42309.

\section{References}

1. Guerrite-Voegelein, F.; Guenard, D.; Potier, P. J. Nat. Prod. 1987, 50, 9.

2. Wani, M. C.; Taylor, H. L.; Wall, M. E.; Coggon, P,; McPhail, A. T. J. Am. Chem. Soc. 1971, 93, 2325.

3. Rowinsky. E. K.; Burke, P. J.; Karp, J. E.; Tucker, R. W.; Ettinger, D. S.; Donehower, R. C. Cancer Res. 1989, 49, 4640.

4. Grem, J. L.; Tutsch, K. D.; Simon, K. J; Alberti, D. B.; Willson, J. K.; Tormey, D. C.; Swaminathan, S.; Trump, D. L. Cancer Treat. Rep. 1978, 71, 1179.

5. Wiemik, P. H.; Scheartz, E. L.; Strauman, J. J. Dutcher, J. P.; Lipton, R. B.; Paietta, E. Cancer Res. 1987, 47, 2484.

6. Donehower, R. C.; Rowinsky, E. K; Grochow, L. B.; Longnecker, S. M.; Ettinger, D. S. Cancer Treat. Rep. 1987, 71, 1171.
7. Longnecker, S. M.; Donehower, R. C.; Cates, A. E.; Chen, T. L.; Brundrett, R. B.; Grochow, L. B; Ettinger, D. S.; Colvin, M. Cancer Treat. Rep. 1987, 71, 53 .

8. McGuire, W. P.; Rowinsky, E. K; Rosenshein, N. B.; Grumbine, F. C.; Ettinger, D. S.; Armstrong, D. K.; Donehower, R. C. Ann. Int. Med. 1989, 111, 273.

9. Margi, N. F.; Kingston, D. G. I. J. Org. Chtm. 1986, 51, 797.

10. Slowikowski, D. L.; Schram, K. H. Biomed. Mass Spectrom. 1985, 12, 72 .

11. Reddy, A. M.; Mykytyn, V. V.; Schram, K. H. Biomed. Enziron. Mass Spectrom. 1989, 18, 1087.

12. Senilh, V.; Blechert, S.; Colin, M.; Guenard, D.; Picot, F.; Potier, P.; Varenne, P. J. Nat. Prod. 1984, 47, 131.

13. Biemann, K.; DeJongh, D. C.; Schnoes, H. K. J. Am. Chem. Soc. $1963,85,1763$.

14. Kurono, M.; Nakadaira, Y,; Onuma, S.; Sasaki, K.; Nakanishi, K. Tett. Lett. 1963, 2153.

15. Porter, Q. N. Mass Spectrometry of Heteracyclic Compounds, 2nd ed.; Wiley: New York, 1985; $\mathrm{p} 38$.

16. McLafferty, F. Interpretation of Mass Spectra, 3rd ed.; University Science Books: Mill Valley, CA, 1980; p 73. 